\title{
PRODUCTION OF LYTIC ENZYMES BY TRICHODERMA ISOLATES DURING IN VITRO ANTAGONISM WITH ASPERGILLUS NIGER, THE CAUSAL AGENT OF COLLAR ROT OF PEANUT
}

\author{
H. P. Gajera*; D. N. Vakharia
}

Department of Biotechnology, College of Agriculture, Junagadh Agricultural University, Junagadh-362 001, Gujarat, India.

Submitted: November 16, 2009; Returned to authors for corrections: February 23, 2011; Approved: January 16, 2012.

\begin{abstract}
Twelve isolates of Trichoderma (six of $T$. harzianum, five of $T$. viride, one of $T$. virens), which reduced variably the incidence of collar rot disease caused in peanut by Aspergillus niger Van Tieghem, were evaluated for their potential to produce lytic enzymes during in vitro antagonism. T. viride 60 inhibited highest $(86.2 \%)$ growth of test fungus followed by T. harzianum $2 \mathrm{~J}(80.4 \%)$ at 6 days after inoculation (DAI) on PDA media. The specific activities of chitinase, $\beta$-1,3-glucanase and protease were 11, 3.46 and 9 folds higher in $\mathrm{T}_{6}$ antagonist (T. viride 60 and A. niger interactions) followed by 8.72, 2.85 and 9 folds in $\mathrm{T}_{8}$ antagonist (T. harzianum $2 \mathrm{~J}$ and A. niger interactions), respectively, compared to the activity produced by control petri plate $\mathrm{T}_{13}$ (A. niger alone) at 6 DAI. Activity of these lytic enzymes induced in antagonists' plates comprises the growth of Trichoderma isolates. However, cellulase and poly galacturonase were found least amount in these antagonists treatment. A significant positive correlation $(p=0.01)$ between percentage growth inhibition of test fungus and lytic enzymes - (chitinase, $\beta$-1,3-glucanase and protease) in the culture medium of antagonist treatment established a relationship to inhibit growth of fungal pathogen by increasing the levels of these enzymes. Among the Trichoderma isolates, T. viride 60 was found best strain to be used in biological control of plant pathogen A. niger.
\end{abstract}

Key words: Trichoderma isolates, Aspergillus niger, Lytic enzymes, Antagonistic interaction.

\section{INTRODUCTION}

Aspergillus is a group of moulds, which is found every where world-wide, especially in the autumn and winter in the Northern hemisphere. Aspergillus niger Van Tieghem is included in subgenus Circumdati, section Nigri. The section Nigri includes 15 related black-spored species that may be confused with A. niger, including A. tubingensis, A. foetidus, A. carbonarius, and A. awamori $(28,42)$. A number of morphologically similar species were described by Samson et al. (42).

A. niger causes a disease called black mold on certain fruits and vegetables such as grapes, onions, and peanut, and is a common contaminant of food. It is ubiquitous in soil and is commonly reported from indoor environments, where its black colonies can be confused with those of Stachybotrys (species

*Corresponding Author. Mailing address: Department of Biotechnology, College of Agriculture, Junagadh Agricultural University, Junagadh-362 001, Gujarat, India.; E-mail: harsukhgajera@yahoo.com 
of which have also been called "black mold") (43). Some strains of $A$. niger have been reported to produce potent mycotoxins called ochratoxins (1). The A. niger causing collar rot disease on peanut seedlings was first reported by Jochem (22). However, Jain and Nema (21) first reported the Aspergillus blight of peanut caused by A. niger in India. This disease appears in two phases pre-emergence and postemergence phase.

A. niger may cause as an average 5 percentage loss in yield but in some parts it may cause as high as 40 percentage losses in Peanut. Collar rot is more serious problem in sandy soil $(9,17)$. In India, the losses may amount to 40 to 50 percentage in terms of mortality of plants due to A. niger (2, 16). Management of collar rot disease can be achieved by use of tolerant varieties and adjustment of sowing dates (16). However, several factors influence the efficacy of these management practices, including pathogenic variability in the fungus populations as well as abiotic factors such as temperature and moisture. Fungicides and organic compounds are widely used to control this disease. However, the degradation of fungicides and organic compounds are very difficult and it's accumulation in food chains is leading to higher toxic level in animals including humans $(8,33)$.

In this context, novel biocontrol agents have, therefore, been looked for (5) and Trichoderma have been the preferred choice. Besides other mode of action, lytic enzymes such as chitinases, $\beta-1,3$ glucanases and proteases have been associated with the ability of Trichoderma spp to control plant pathogens (4). Three strains of Trichoderma (T. harzianum, T. viride, $T$. virens) were found to impair the progress of collar rot disease in field conditions caused in peanut by A. niger.

Trichoderma isolates (twelve isolates of three Trichoderma strains) could not work equally against specific phytopathogen. Hence, the objective of this study is to find out the best Trichoderma isolate as a biocontrol agent which effectively inhibits in vitro the growth of $A$. niger on solid PDA media. These Trichoderma isolates are correlated on the production of lytic enzymes (cellulase, poly galacturonase, chitinase, $\beta-1,3$ glucanse and protease activities in the presence of corresponding substrate) during antagonism with A. niger.

\section{MATERIALS AND METHODS}

\section{Isolation and maintenance of microbes}

Peanut seedlings which showed typical symptoms of collar rot were cut into small bits with the help of sterilized blade and the pure culture of pathogen (A. niger) was made by hyphal tip isolation method (45) on the solidified PDA medium in petri plates. A typical black mycelium (conidia) growth of $A$. niger was observed after $72 \mathrm{~h}$ of incubation at $28 \pm 1{ }^{\circ} \mathrm{C}$ in an incubator. Virulence of isolated pathogen- A. niger was also tested on peanut seed.

Twelve isolates of Trichoderma (six of T. harzianum, five of $T$. viride, one of $T$. virens) were obtained from culture Collection of Department of Plant Pathology, College of Agriculture, Junagadh Agricultural University, Junagadh, Gujarat, India. All microbes including pathogen were maintained throughout the study by periodical transfers on PDA medium under aseptic condition to keep the culture fresh and viable.

\section{Antagonistic capacity of Trichoderma isolates}

The in vitro antagonism experiments were accomplished by the method described by Dennis and Webster (13). The isolates were cultivated in petri plates with PDA media for seven days. Disks of $5 \mathrm{~mm}$ of diameter cut and removed from the growing borders of the colonies and transferred to another petri plate with PDA. Each plate received two disks, one with Trichoderma mycelium and another with A. niger, placed at a distance of $7 \mathrm{~cm}$ away from each other. The experiment was conducted in five replications for each antagonist. The plates were incubated at $28 \pm 1^{0} \mathrm{C}$ temperatures and observed after six days for growth of antagonist and test fungus. Index of antagonism as percentage growth inhibition of $A$. niger was 
determined by following the method of Watanabe (47).

\section{Extraction of lytic enzymes}

Crude enzyme extract was prepared from petri plates containing fungal pathogen and Trichoderma as well as the test fungus alone as a control (C) at 6 days after inoculation (DAI). For that, $25 \mathrm{ml}$ of $100 \mathrm{mM}$ phosphate buffer (pH-5.5) containing $50 \mathrm{mM}$ sodium chloride was added to each petri plate and transferred mycelia mat to conical flask. For enzyme induction, $1 \%$ of either carboxymethyl cellulose (CMC), sodium polypectate, chitin, laminarin or casein was added into culture medium of conical flask and $\mathrm{pH}$ adjusted to 5.5 (26, 35). Cultures were then shaken well in orbital shaker at 120 $\mathrm{rpm}$ at $28^{\circ} \mathrm{C}$ for about 6 hours (46). After that, it was transferred to $50 \mathrm{ml}$ centrifuge tubes and centrifuged at 14,000 rpm for $10 \mathrm{~min}$. Supernatant was collected and stored at $-20^{\circ} \mathrm{C}$ until use for assay of enzymes activities (cellulase, poly galacturonase (PG), chitinase, $\beta-1,3$ glucanase, protease). The method of Folin-Lowry (32) was used to determine protein content in culture supernatant and to calculate the specific activity of the enzyme.

\section{Enzymes assays}

Cellulase activity (EC 3.2.1.21): Suitable aliquot (100 $\mu \mathrm{l})$ of the culture supernatant was incubated with $400 \mu \mathrm{l}$ of $100 \mathrm{mM}$ sodium citrate buffer $(\mathrm{pH} \mathrm{5.2)}$ containing $1 \% \mathrm{CMC}$ (12). After incubation at $55^{\circ} \mathrm{C}$ for $15 \mathrm{~min}$., the glucose released was measured by the dinitrosalicylic acid (DNSA) method (41). A known volume of aliquot was taken in test tube and final volume of $1.0 \mathrm{ml}$ adjusted with distilled water. To this, $0.5 \mathrm{ml}$ DNSA reagent (1g DNSA + 200mg crystalline phenol + $50 \mathrm{mg}$ sodium sulphite in $100 \mathrm{ml}$ of $1 \%$ sodium hydroxide) was added and mixed properly. The content was heated in boiling water bath for $5 \mathrm{~min}$. When the contents of the tubes were still warm, $1.0 \mathrm{ml}$ of $40 \%$ sodium potassium tartrate (Rochelle salt) solution was added and cooled. The final volume was made 5.0 $\mathrm{ml}$ with distilled water and read at 540nm using spectrophotometer. Reagent blank was also performed by addition of $1.0 \mathrm{ml}$ of distilled water in place of enzyme aliquot and treated in the same way as above procedure. A known concentration of standard of glucose was calibrated by following the above procedure and the enzyme activity expressed as appropriate.

Poly galacturonase (PG) activity (EC 3.2.1.15): The culture supernatants $(100 \mu \mathrm{l})$ were incubated with $400 \mu \mathrm{l}$ of $50 \mathrm{mM}$ sodium acetate buffer $(\mathrm{pH} 5.2)$ containing $0.25 \%$ sodium polypectate (12). After incubation at $37^{0} \mathrm{C}$ for $1 \mathrm{~h}$, the galacturonic acid released was measured by the DNSA method (41).

Chitinase activity (EC 3.2.1.14): Reaction mixture contained $200 \mu \mathrm{l}$ of $0.5 \%$ chitin in $10 \mathrm{mM}$ sodium acetate buffer (pH 5.2) and $100 \mu$ l of culture supernatants (6) were incubated for $1 \mathrm{~h}$ at $50^{\circ} \mathrm{C}$. The formation of sugar $\mathrm{N}$ acetylglucosamine was measured by Dimethylamino benzaldehyde (DMAB) method (40). Known aliquot of reaction mixture $(0.5 \mathrm{ml})$ was taken into test tube and $0.5 \mathrm{ml}$, $120 \mathrm{mM}$ potassium borate buffer ( $\mathrm{pH}$ 8.9) was added. The tubes were vigorously boiled in water bath for $3 \mathrm{~min}$. and cooled. Then, $3 \mathrm{ml}$ DMAB reagent $(5.0 \mathrm{~g}$ DMAB dissolved in $500 \mathrm{ml}$ of glacial acetic acid containing $12.5 \% \mathrm{v} / \mathrm{v} 10 \mathrm{~N} \mathrm{HCl}$, stored at $20^{\circ} \mathrm{C}$ as a stock and prior to use, it was diluted with nine volume of glacial acetic acid) was added in each tubes and incubated at $38^{\circ} \mathrm{C}$ for $20 \mathrm{~min}$. Tubes were then cooled and absorbance was measured at $544 \mathrm{~nm}$ in spectrophotometer. Standard N-acetylglucosamine was prepared in borate buffer and measured following the above procedure. The amount of $\mathrm{N}$-acetylglucosamine was calculated and expressed as appropriate.

$\boldsymbol{\beta}-1,3$ glucanase activity (EC 3.2.1.39): The reaction system contained $100 \mu \mathrm{l}$ of $4 \%$ laminarin in $50 \mathrm{mM}$ sodium acetate buffer ( $\mathrm{pH}$ 5.2) and $100 \mu \mathrm{l}$ of culture supernatants (23). Reactions were carried out at $37^{\circ} \mathrm{C}$ for $10 \mathrm{~min}$. After incubation, the glucose released by enzyme $\beta-1,3$ glucanase was measured by DNSA method (41). 
Specific activity of cellulase, PG, chitinase and $\beta-1,3$ glucanase were expressed as Unit.mg ${ }^{-1}$ protein. However, Unit activity was defined as the amount of enzyme necessary to produce one $\mu \mathrm{M}$ of corresponding reducing sugar per min per $\mathrm{ml}$ of culture supernatants. Non enzymatic controls were also performed using boiled enzymes and were subtracted from the enzymatic values.

Protease activity (EC 3.4.21.4): The reaction system contained $500 \mu \mathrm{l}$ enzyme solution and $500 \mu \mathrm{l}$ of $0.36 \%$ casein and $2.0 \mathrm{ml}$ of $100 \mathrm{mM}$ acetate buffer $(\mathrm{pH} 3.6)$. Reactions were allowed to proceed for $1 \mathrm{~h}$ at $50^{\circ} \mathrm{C}$ and stopped with $3 \mathrm{ml}$ of 5 $\%$ trichloroacetic acid (34). Blank was treated as zero time incubation. The reaction mixtures were then centrifuged at $5000 \mathrm{rpm}$ for $10 \mathrm{~min}$. to settle down precipitate and known volume of supernatants $(500 \mu \mathrm{l})$ were used for estimation of released free amino acids by ninhydrin method (30). Specific activity of protease was expressed as Unit.mg ${ }^{-1}$ protein and one unit of protease activity was defined as the amount of protein necessary to produce $\mu \mathrm{g}$ free amino acids per min per $\mathrm{ml}$ of culture supernatant.

\section{RESULTS AND DISCUSSION}

\section{In vitro percentage growth inhibition of $A$. niger}

Growth inhibition of $A$. niger during in vitro interaction with bio-control agents Trichoderma at 6 DAI was depicted in Fig. 1 and 2. Percentage growth inhibition of pathogen $(A$. niger) was significantly higher in $\mathrm{T}_{6}(86.2 \%)$ antagonist followed by $\mathrm{T}_{8}(80.4 \%), \mathrm{T}_{3}(74.3 \%), \mathrm{T}_{2}(71.9 \%), \mathrm{T}_{1}(60.9 \%)$ and $\mathrm{T}_{12}(50.6 \%)$ at 6 DAI. Non significant differences were observed between antagonists $\mathrm{T}_{5}(42.4 \%)$ and $\mathrm{T}_{10}(40.2 \%)$ However, other antagonists were recorded below $30 \%$ growth inhibition of fungal pathogen. Thus, it was observed that $\mathrm{T}_{6}$ antagonist (i.e. interaction between Trichoderma viride 60 and pathogen A. niger) have a better growth of inhibition of test fungus $A$. niger as compared to the other bio-control agents. These results are in confirmation with the finding of Kishore and his coworkers (27), who reported that the $T$. viride and $T$. harzianum were found to be effective in reducing the radial growth of A. niger in vitro. Rao and Sitaramaih (39) and Prabhu and Urs (36) also documented that Trichoderma isolates significantly inhibited the growth of A. niger. T. viride had a greater inhibition on A. niger than T. harzianum (Raju and Murthy, 38).
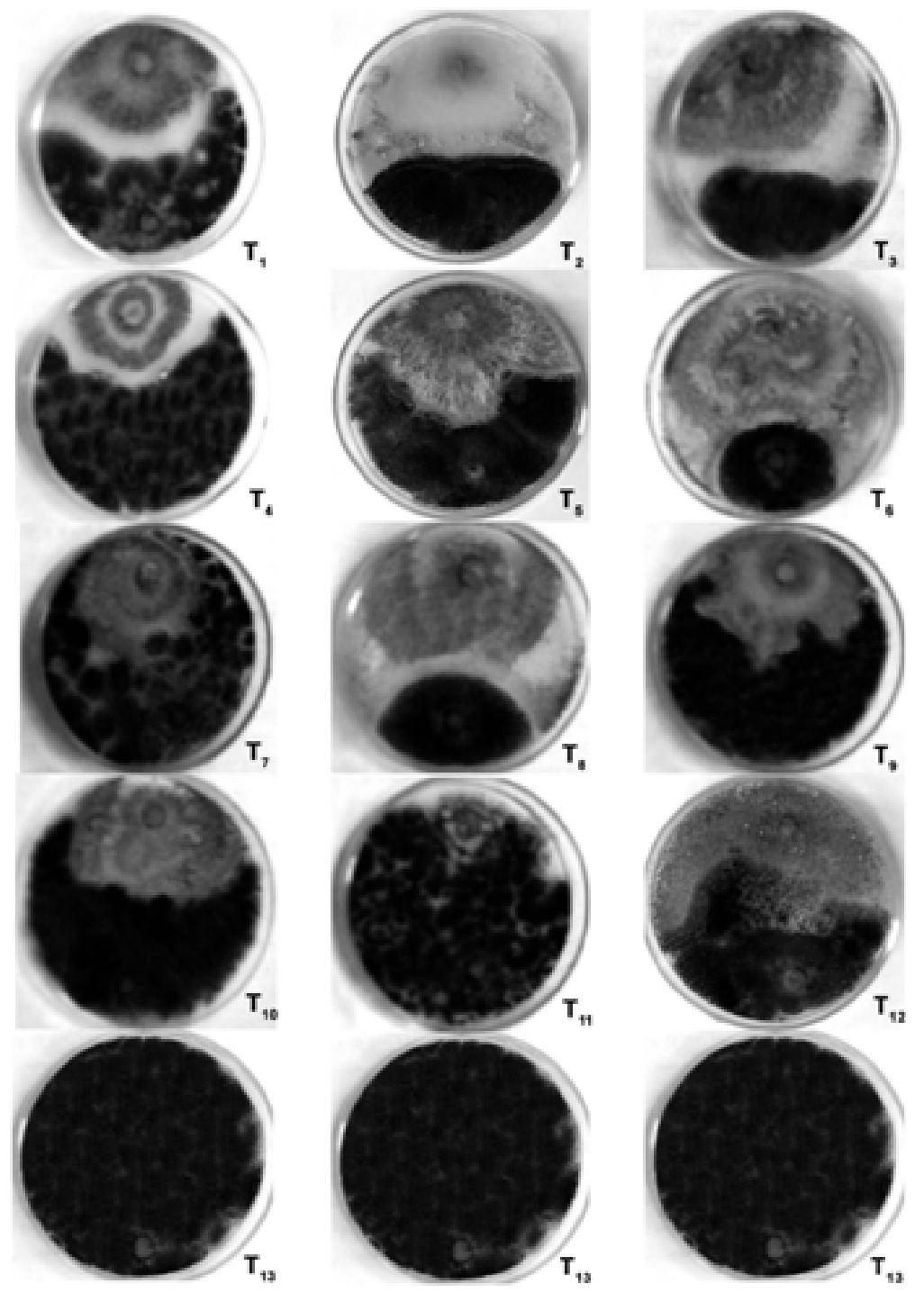

Figure 1. Antagonism between Trichoderma isolates and A. niger at 6 DAI (Antagonists petri dish (T1 to T12) have Trichoderma isolates at the top and pathogen A. niger at the bottom). 


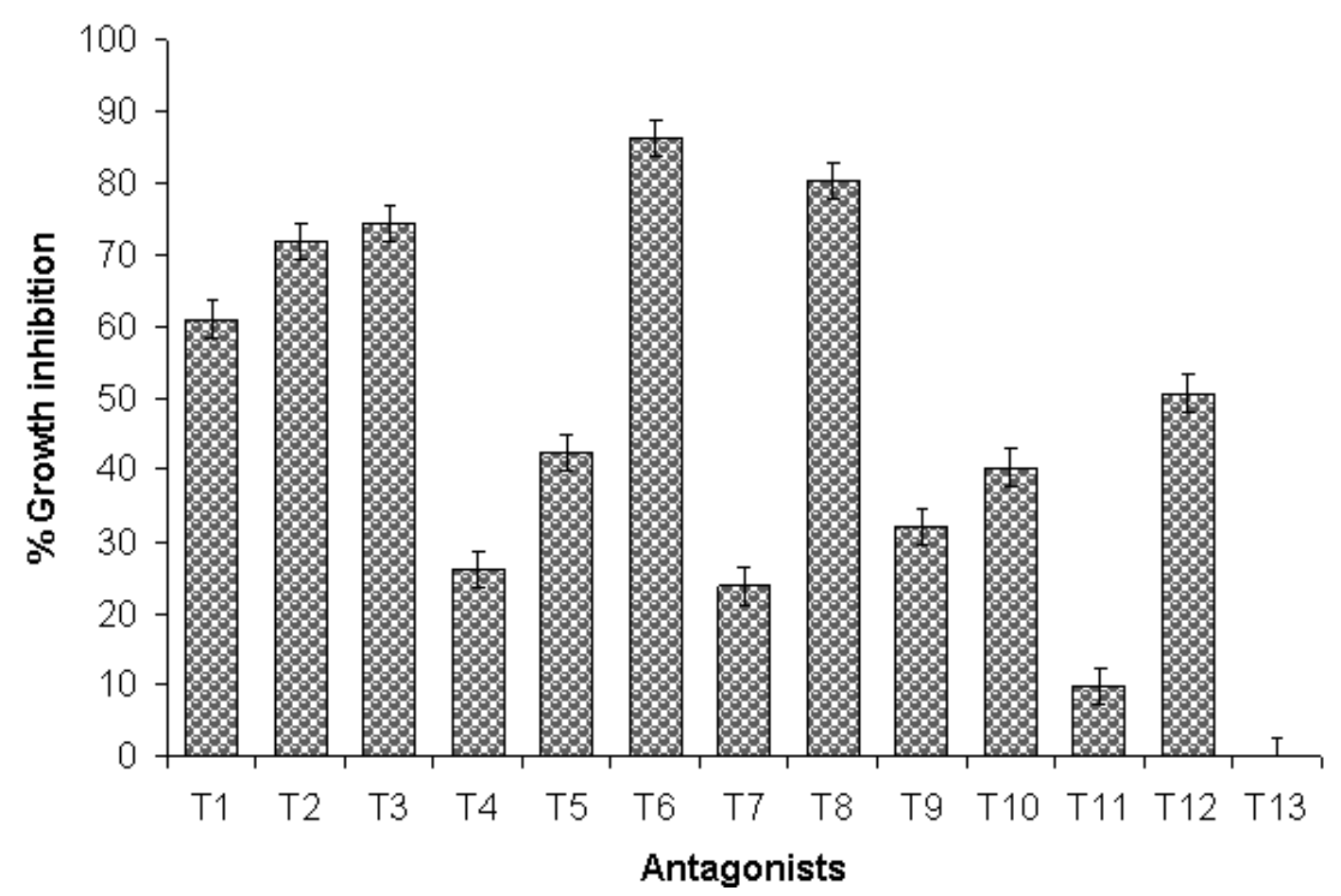

Figure 2. Percentage growth inhibition of Aspergillus niger during in vitro antagonism with Trichoderma at 6 days after inoculation (DAI)

$\mathrm{T}_{1}=T$. virens BAN X A. niger $(\mathrm{AN}) ; \mathrm{T}_{2}=T$. viride $\mathrm{BAN} X \mathrm{AN} ; \mathrm{T}_{3}=T$. viride JND X AN; $\mathrm{T}_{4}=T$. harzianum $\mathrm{BAN} X \mathrm{AN} ; \mathrm{T}_{5}$

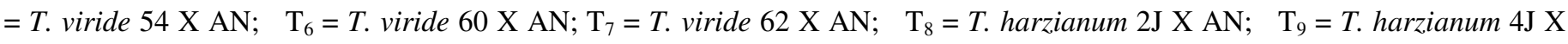
$\mathrm{AN} ; \mathrm{T}_{10}=T$. harzianum 5J X AN; $\mathrm{T}_{11}=T$. harzianum $6 \mathrm{~J}$ X AN; $\mathrm{T}_{12}=T$. harzianum JND X AN; $\mathrm{T}_{13}=\mathrm{Control}-$ A. Niger $(\mathrm{AN}) ;$ Error bar indicates $\mathrm{CD}$ value at $5 \%$

The antagonistic effect of Trichoderma sp. and Pseudomonas fluorescence against isolates of Fusarium oxysporum f. sp. carthami that causes wilt disease in sunflower was studied by Prameala et al. (37). Among three antagonists tested, $T$. viride was found to be more effective than $T$. Harzianum and $P$. fluorescens which confirm the present experimental results that $T$. viride was the best antagonist than T. harzianum and T. virens. Seventy Trichoderma isolates collected from different regions of Morocco were tested for their capacity to inhibit in vitro mycelial growth of Sclerotium rolfsii (24). Four of these isolates ( $\mathrm{Nz}, \mathrm{Kb} 2, \mathrm{~Kb} 3$ and $\mathrm{Kf1}$ ) showed good antagonistic activity against $S$. rolfsii and were also highly competitive in natural soil. These isolates would therefore be candidates for development in biological control. Shalini and Kotasthane (44) screened seventeen Trichoderma strains against $R$. solani in vitro and found that T. harzianum, T. viride and T. aureoviride were inhibited the growth of $R$. solani.

\section{Lytic enzymes}

The results on in vitro production of various lytic enzymes such as cellulase, poly galacturonase (PG), chitinase, $\beta-1,3$ glucanase and protease during antagonism of Trichoderma isolates with test fungus $A$. niger in the culture medium at 6 DAI is presented below.

Cell Wall Degrading Enzymes (CWDEs): Specific 
activity of cellulase was significantly higher in control (A.

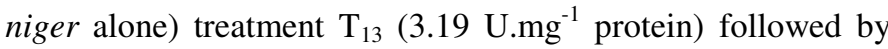
antagonist $\mathrm{T}_{9}$ (2.71), $\mathrm{T}_{11}$ (2.64), $\mathrm{T}_{10}$ (2.33), $\mathrm{T}_{4}(2.26)$ and $\mathrm{T}_{12}$ (2.03) at $6 \mathrm{DAI}$ (Fig 3A). The significantly minimum cellulase activity (0.93 U.mg ${ }^{-1}$ protein) was found in culture medium of $\mathrm{T}_{6}$ (interaction between pathogen and $T$. viride 60 ) followed by $\mathrm{T}_{8}$ (1.35), $\mathrm{T}_{2}$ (1.47), $\mathrm{T}_{3}$ (1.50) and $\mathrm{T}_{1}$ (1.59). Specific activity of PG was also significantly higher in $\mathrm{T}_{13}$ (6.73 $\mathrm{U.mg}^{-1}$ protein) followed by $\mathrm{T}_{10}(6.19), \mathrm{T}_{5}(5.89), \mathrm{T}_{7}(5.64), \mathrm{T}_{9}(5.31)$ and $\mathrm{T}_{11}$ (5.00) at 6 DAI (Fig 3A). The significantly minimum PG activity (2.01 U.mg ${ }^{-1}$ protein) was found in culture medium of $\mathrm{T}_{8}$ (interaction between pathogen and $T$. harzianum $2 \mathrm{~J}$ ) followed by $\mathrm{T}_{6}(3.14), \mathrm{T}_{3}(3.60), \mathrm{T}_{2}$ (3.64) and $\mathrm{T}_{1}$ (3.93).

The activity of cellulase and PG in the culture medium reduced when the growth of Trichoderma isolates more during antagonism with test fungus in $\mathrm{T}_{6}$ and $\mathrm{T}_{8}$. While, the same activities were higher in $\mathrm{T}_{13}$ (A. niger alone). The cell wall of either bio-control agents - Trichoderma or host plant is the first barrier encountered by most plant pathogens, and thus it must be degraded to allow their (pathogen) penetration and tissue colonization. Necrotrophic fungal pathogens degrade the structural polymers in host cell wall and colonize the inter cellular spaces facilitated by the production of cell wall degrading enzymes (CWDEs). Kishore and his group (26) found that cell free culture filtrate of bio-agent Pseudomonas aeruginosa GSE 18 at $25 \%$ dilutions inhibited the in vitro production of $A$. niger CWDEs such as cellulase and PG which support our findings. This mechanism might have a significant role in control of collar rot disease by diminishing the virulence of $A$. niger in the peanut rhizosphere.

Among the different pectinolytic enzymes, PG was the most notable (7), since it facilitated the penetration of primary host cell walls. Production of CWDEs (Cellulase and PG) determined the pathogenicity of necrotrophic pathogen (11). Inhibition of these CWDEs production leads to the reduction in virulence of fungal pathogens.

Pathogenesis related enzymes: Chitinase activity was the highest (1.31 U.mg-1 protein) in the culture medium of $\mathrm{T}_{6}$ and slightly reduced to $1.07 \mathrm{U} \cdot \mathrm{mg}^{-1}$ protein in $\mathrm{T}_{8}, 0.90 \mathrm{U} \cdot \mathrm{mg}$ ${ }^{1}$ protein in $\mathrm{T}_{3}, 0.72 \mathrm{U} \mathrm{mg}^{-1}$ proteins in $\mathrm{T}_{1}$ (Fig. 3B). It was significantly reduced to $0.44 \mathrm{U}_{\mathrm{mg}} \mathrm{mprotein}^{-1}$ in $\mathrm{T}_{5}$ and $\mathrm{T}_{9}$ antagonists followed by $\mathrm{T}_{10}, \mathrm{~T}_{4}, \mathrm{~T}_{7}, \mathrm{~T}_{12}$ and $\mathrm{T}_{13}$ antagonists. The lowest chitinase activity (0.11 U.mg ${ }^{-1}$ protein) was recorded in $\mathrm{T}_{13}$ (culture medium of test fungus as a control). Chitinase activity was higher during antagonism when antagonist effectively inhibited the growth of test fungus ( $A$. niger).

Marco and his coworkers (35) noted that two isolates of $T$. harzianum (39.1 and 1051) produced and secreted on induction substantial amounts of chitinolytic enzymes and it increased within $72 \mathrm{~h}$ and maximal activity $\left(0.39 \mathrm{U}^{-\mathrm{ml}^{-1}}\right)$ was produced by isolate 1051 . This activity was 13 fold higher than those determined for the 39.1 (0.013 ${\left.\mathrm{U} . \mathrm{ml}^{-1}\right)}^{-}$strains. Thus, isolates of Trichoderma showed variation in production of chitinase activity which supports our results. Kucuk and Kivank (29) found that all filtrates of Trichoderma harzianum $\mathrm{T}_{9}, \mathrm{~T}_{10}, \mathrm{~T}_{15}$ and $\mathrm{T}_{19}$ were effective against plant pathogens Fusarium culmarum, F. oxysporum, F. moniliforme, R. solani, Sclerotium rolfsii, Gaeumannomyces graminis var. tritici and Drechslera sorokiniana. Among these isolates, $T$. harzianum $\mathrm{T}_{19}$ showed a wide range of inhibitory effects on plant pathogens. Transformants of the biocontrol agent $T$. harzianum strain CECT 2413 that over expressed a $33 \mathrm{kDa}$ chitinase (chit33) were obtained and characterized (31).

The specific activity of $\beta-1,3-$ Glucanase recorded its

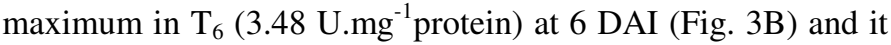
was significantly reduced to $3.01 \mathrm{U} \cdot \mathrm{mg}^{-1}$ protein during $\mathrm{T}_{8}$ antagonism followed by $\mathrm{T}_{2}$ (2.15), $\mathrm{T}_{3}$ (1.95), $\mathrm{T}_{1}$ (1.87), $\mathrm{T}_{4}$ (1.78), $\mathrm{T}_{5}$ (1.72), $\mathrm{T}_{9}(1.64), \mathrm{T}_{7}(1.09), \mathrm{T}_{13}(0.78), \mathrm{T}_{11}(0.63), \mathrm{T}_{10}$ $(0.42)$ and $\mathrm{T}_{12}(0.40)$ at 6 DAI. Surprisingly, antagonists $\mathrm{T}_{11}$, $\mathrm{T}_{10}$ and $\mathrm{T}_{12}$ had lower $\beta$-1,3-glucanase activity than control $\mathrm{T}_{13}$ (test fungus) but the differences were non significant. The activity of $\beta-1,3$ glucanase was the highest in $\mathrm{T}_{6}$ antagonist (results from the interaction between $T$. viride 60 and test 
fungus- A. niger) followed by $\mathrm{T}_{8}$ (interaction effect of $T$. harzianum $2 \mathrm{~J}$ and test fungus). These were corresponded to the maximum growth inhibition of pathogen A. niger by $\mathrm{T}_{6}(86.2 \%)$ antagonist followed by $\mathrm{T}_{8}(80.4 \%)$.

Glucanolytic enzyme activity was found maximum in Trichoderma isolates during 72 to $120 \mathrm{~h}$ growth in presence of specific substrate (35). It has been shown that $\beta-1,3$ glucanase inhibit the spore germination or the growth of pathogens in synergistic cooperation with chitinases $(3,15)$ and antibiotics $(18$, 25). Many $\beta$-1,3-glucanases have been isolated, but only a few genes have been cloned, e.g. bgn13.1 (3) and lam1.3 (10) from T. harzianum, glu78 (14) from T. atroviride, and Tv-bgnl and Tvbgn2 (25) from $T$. virens. However, only strains over expressing bgn13.1 from T. harzianum have been constructed.

When expressing specific activity of protease in U.mg ${ }^{1}$ protein (Fig. 3B), the highest activity was found in $\mathrm{T}_{8}(5.63)$ followed by $\mathrm{T}_{6}, \mathrm{~T}_{11}, \mathrm{~T}_{2}, \mathrm{~T}_{12}, \mathrm{~T}_{3}, \mathrm{~T}_{1}, \mathrm{~T}_{9}, \mathrm{~T}_{5}, \mathrm{~T}_{4}, \mathrm{~T}_{10}, \mathrm{~T}_{7}$ and $\mathrm{T}_{13}$ antagonists in the culture medium at 6 DAI. The enzyme activity was more or less correlated with growth inhibition of test fungus except $\mathrm{T}_{11}$ antagonist. The specific activity of protease attained highest in $\mathrm{T}_{8}$ antagonism (T. harzianum $2 \mathrm{~J}$ x test fungus $A$. niger) followed by $\mathrm{T}_{6}$ (T. viride $60 \mathrm{x}$ test fungus). However, maximum growth inhibition of pathogen $A$. niger was achieved by $\mathrm{T}_{6}$ antagonist followed by $\mathrm{T}_{8}$.

Filamentous fungal cell wall also contains lipids and proteins (20). It, therefore, was expected that antagonistic fungi synthesized proteases which may act on the host cell-wall. The T. harzianum isolates 1051 and TVC secreted equivalent amounts (1.41 U.ml ${ }^{-1}$ ) of proteolytic activity after $72 \mathrm{~h}$ of growth. These activities were significantly higher than the produced by $T$. harzianum strain 39.1 (0.86 U.ml ${ }^{-1}$ ) under the same conditions (35). Bio-control of $B$. cinerea by $T$. harzianum has been attributed to the action of proteases produced by the bio-control agent that inactivate hydrolytic enzymes produced by the pathogen (19).

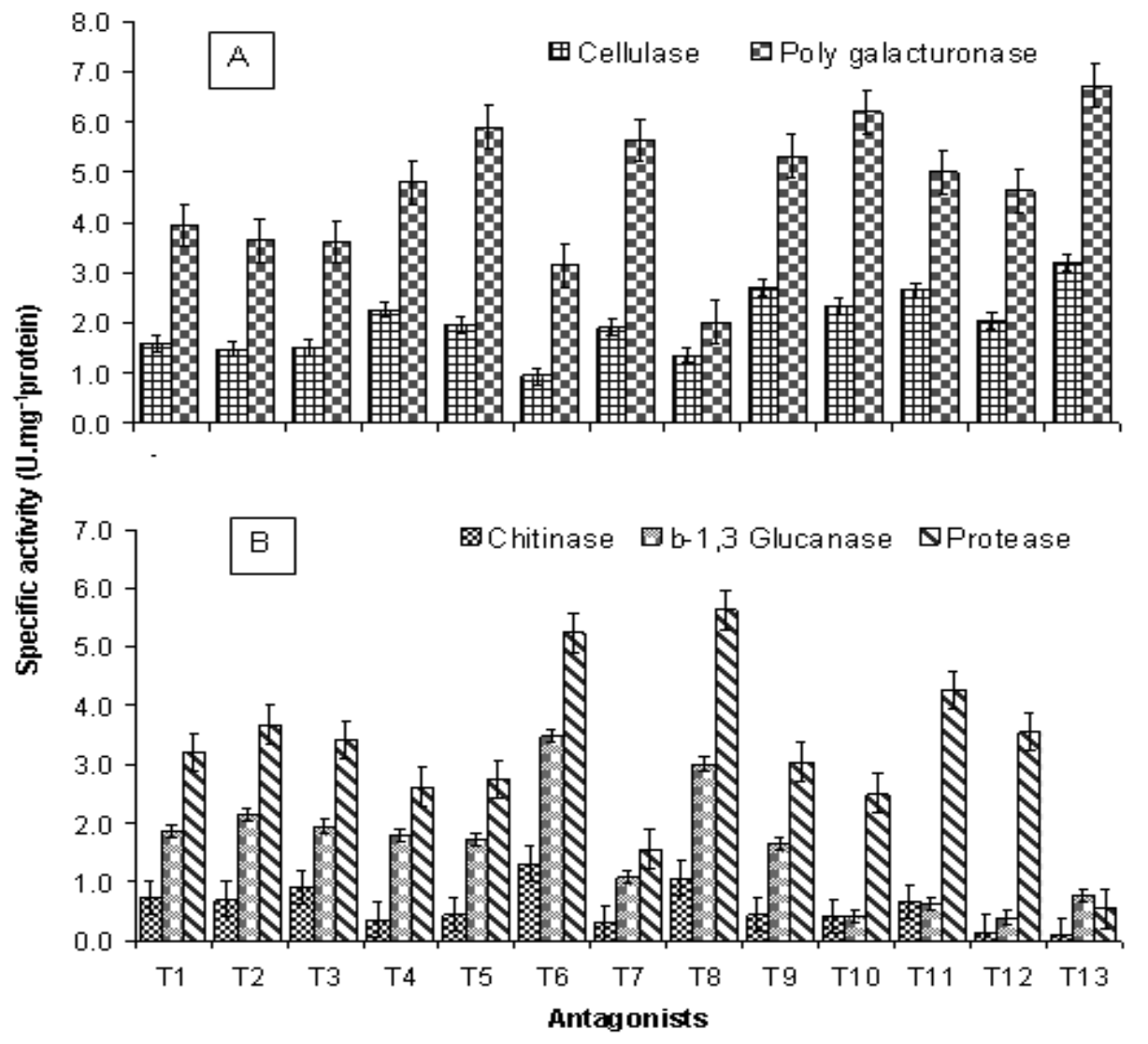

Figure 3. In vitro production of cell wall degrading enzymes (A) and pathogenesis related enzymes (B) in the culture medium at 6 days after inoculation (DAI).

$\mathrm{T}_{1}=T$. virens BAN X A. niger $(\mathrm{AN})$; $\mathrm{T}_{2}=T$. viride BAN X AN; $\quad \mathrm{T}_{3}=T$. viride JND $\mathrm{X} \mathrm{AN} ; \mathrm{T}_{4}=T$. harzianum $\mathrm{BAN} X \mathrm{AN} ; \mathrm{T}_{5}=T$. viride $54 \mathrm{X} \mathrm{AN}$; $\mathrm{T}_{6}=T$. viride $60 \mathrm{X} \mathrm{AN} ; \mathrm{T}_{7}=T$. viride $62 \times \mathrm{AN} ; \quad \mathrm{T}_{8}=T$. harzianum $2 \mathrm{~J} \mathrm{X}$ AN; $\quad \mathrm{T}_{9}=T$. harzianum 4J X AN; $\mathrm{T}_{10}$ $=T$. harzianum $5 \mathrm{~J}$ X AN; $\quad \mathrm{T}_{11}=T$. harzianum $6 \mathrm{~J} \quad \mathrm{X} \quad \mathrm{AN} ; \mathrm{T}_{12}=T$. harzianum JND X AN; $\quad \mathrm{T}_{13}=$ Control - A. Niger (AN); Error bar indicates $\mathrm{CD}$ value at $5 \%$ 


\section{Correlation between percentage growth inhibition of fungal pathogen and lytic enzymes}

The correlation between percentage growth inhibitions of A. niger and CWDEs cellulase and PG showed significant $(p=0.01)$ negative relationship (Table 1). This suggested that percentage growth inhibition decreased with increasing concentration of cellulase and PG in the culture medium at 6 DAI. A significant positive correlation $(p=0.01)$ between percentage growth inhibition of test fungus and activities of chitinases, $\beta$-1,3-glucanase and protease enzymes in the culture medium of antagonists established a relationship to inhibit the growth of fungal pathogen by increasing the levels of these lytic enzymes. However, CWDEs cellulase and PG were significantly negatively correlated with pathogenesis related enzymes mainly chitinase and $\beta$-1,3-glucanase. While, positive correlation was established among the protease and pathogenesis related enzymes- chitinase and $\beta$-1,3-glucanase.

So, it can be summarized that pathogen A. niger secreted cellulase and PG in culture medium as maximum level of these enzymes were observed in control $\mathrm{T}_{13}$. However, enzymes related to Trichoderma chitinases, $\beta-1,3$ glucanase and protease was released during antagonism and inhibited the growth of fungal pathogen. Among the 12 bio-control agents of Trichoderma, $T$. viride 60 was the best agent to inhibit the growth of fungal A. niger on PDA media. Thus, T. viride 60 is the most suitable strain to be used in biological control of plant pathogen A. niger causing collar rot disease in peanut seedlings.

Table 1. Correlation matrix between percentage growth inhibition of A. niger and production of lytic enzymes during antagonism in the culture medium at 6 days after inoculation (DAI).

\begin{tabular}{|c|c|c|c|c|c|c|}
\hline & $\begin{array}{l}\text { \% Growth } \\
\text { Inhibition }\end{array}$ & Cellulase & $\begin{array}{c}\text { Poly galac- } \\
\text { turonase (PG) }\end{array}$ & Chitinase & $\begin{array}{c}\boldsymbol{\beta}-1,3 \\
\text { Glucanase }\end{array}$ & Protease \\
\hline$\%$ Growth Inhibition & 1.000 & & & & & \\
\hline Cellulase & $-0.9196^{* *}$ & 1.0000 & & & & \\
\hline PG & $-0.8443^{* *}$ & $0.8108 * *$ & 1.0000 & & & \\
\hline Chitinase & $0.7462 * *$ & $-0.7529 * *$ & $-0.8221 * *$ & 1.0000 & & \\
\hline$\beta-1,3$ Glucanase & $0.7811 * *$ & $-0.7744 * *$ & $-0.7726 * *$ & $0.84046 * *$ & 1.0000 & \\
\hline Protease & $0.7223 * *$ & $-0.6667 *$ & $-0.8557 * *$ & $0.81501 * *$ & $0.63233 *$ & 1.00000 \\
\hline
\end{tabular}

\section{ACKNOWLEDGEMENTS}

Authors are thankful to Professor and Head, Department of Plant Pathology, JAU, Junagadh for providing slants of twelve Trichoderma isolates.

\section{REFERENCES}

1. Abarca, M.; Bragulat, M.; Castellá, G.; Cabañes, F. (1994). OchratoxinA production by strains of Aspergillus niger var. niger. Appl. Environ. Microbiol., 60, 2650-2652.

2. Aulakh, K.S.; Sandhu, R.S. (1970). Reaction of groundnut varieties against Aspergillus niger. Pl. Dis. Res., 54, 337.

3. Benítez, T.; Delgado-Jarana, J.; Rincón, A.M.; Rey, M.; Limón, M.C. (1998). Biofungicides: Trichoderma as a biocontrol agent against phytopathogenic fungi. In: Recent research developments microbiology Pandalai SG (ed), vol. 2. Research Signpost, Trivandrum, pp 129-150.,

4. Benítez, T.; Rincón, A.; Carmen Limón, M.; Codón, A.C. (2004). Biocontrol mechanisms of Trichoderma strains. Intl. Microbiol., 7, 249260

5. Boland, G.J. (1990). Biological control of plant diseases with fungal antagonists: challenges and opportunities. Can. J. Plant Pathol., 12, 295 299.

6. Boller, T.; Mauch, F. (1988). Colorimetric assay of Chitinase. Methods Enzymol., 161, 431-435.

7. Carder, J.H.; Hignett, R.C.; Swinburne, T.R. (1987). Relationship 
between the virulence of hop isolates of Verticillium alboatrum and their in vitro secretion of cell wall degrading enzymes. Physiol. Mol. Plant Pathol., 31, 441-452.

8. Chet, I. (1987). Trichoderma Application, Mode of Action and Potential as a Biocontrol Agent of Soil-borne Plant Pathogenic Fungi. In: Innovative Approaches to Plant Disease Control, ed. Chet I., Wiley, New York, pp. 137-160.

9. Chohan, J.S. (1965). Collar rot of groundnut caused by A. niger in the Punjab. J. Res., PAU, 3, 25-33.

10. Cohen-Kupiec, R.; Broglie, K.E.; Friesem, D.; Broglie, R.M.; Chet, I. (1999). Molecular characterization of a novel $\beta-1,3$ exoglucanase related to mycoparasitism of Trichoderma harzianum. Gene, 226: 147-154.

11. Collmer, A.; Keen, N.T. (1986). The role of pectic enzymes in plant pathogenesis. Annual Rev. Phytopathol., 24, 383-409.

12. Collmer, A.; Reid, J.L.; Mount, M.S. (1988). Assay methods for pectic enzymes. In: Methods Enzymol., 161: 329-335.

13. Dennis, C.J.; Webster, J. (1971). Antagonism properties of species groups of Trichoderma, III Hyphal interaction. Trans. Brit. Myco. Soc., 57, 363-369.

14. Donzelli, B.G.; Lorito, M.; Scala, F.; Harman, G.E. (2001). Cloning, sequence and structure of a gene encoding an antifungal glucan 1,3-âglucosidase from Trichoderma atroviride (T. harzianum). Gene, 277, 199-208.

15. El-Katatny, M.H.; Gudelj, M.; Robra, K.H.; Elnaghy, M.A.; Gubitz, G.M. (2001). Characterization of a chitinase and an endo- $\beta-1,3-$ glucanase from Trichoderma harzianum Rifai T24 involved in control of the phytopathogen Sclerotium rolfsii. Appl. Microbiol. Biotechnol., 56, $137-143$.

16. Ghewande, M.P.; Desai, S.; Basu, M.S. (2002). Diagnosis and management of major diseases of groundnut, NRCG Bulletin, pp 8-9.

17. Gibson, I.A.S. (1953). Crown rot seedling diseases of groundnut caused by A. niger II. Anomalour effect of orange mercurial seed dressings. Trans. Br. Mycol. Soc., 36, 324-334.

18. Harman, G.E.; Howell, C.R.; Viterbo, A.; Chet, I.; Lorito, M. (2004). Trichoderma species- opportunistic, avirulent plant symbionts. Nature Reviews 2, 43-56.

19. Howell, C.R. (2003). Mechanisms employed by Trichoderma species in the biological control of plant diseases: the history and evolution of current concepts. Plant Dis., 87, 4-10

20. Hunsley, H.D.; Burnett, J.H. (1970). The ultrastructural architecture of the walls of some hyphal fungi. J. Gen. Microbiol., 62, 203-218.

21. Jain, A.C.; Nema, K.G. (1952). Aspergillus blight of groundnut seedling. Sci. Cul., 17, 348-349.

22. Jochem, S.C.J. (1926). Aspergillus niger on groundnut. Indisch culturen (Teysmannia), 11, 325-326.

23. Kauffman, S.; Legrand, M.; Geoffory, P.; Fritig, B. (1987). Biological functions of 'pathogenesis related' proteins four PR proteins of tobacco have $\beta$-1,3- glucanase activity. EMBO Journal, 6, 3209-3212.

24. Khattabi, N.; Ezzahiri, B.; Louali, L.; Oihabi, A. (2004). Antagonistic activity of Trichoderma isolates against Sclerotium rolfsii: screening of efficient isolates from Morocco soils for biological control. Phytopathol. Mediterr., 43, 332-340

25. Kim, D.J.; Baek, J.M.; Uribe, P.; Kenerley, C.M.; Cook, D.R. (2002). Cloning and characterization of multiple glycosyl hydrolase genes from Trichoderma virens. Curr. Genet., 40, 374-384.

26. Kishore, G.K.; Pande, S.; Podile, A.R. (2006). Pseudomonas aeruginosa GSE 18 inhibits the cell wall degrading enzymes of Aspergillus niger and activates defence-related enzymes of groundnut in control of collar rot disease. Aus. Pl. Pathol., 35, 259-263.

27. Kishore; G.K.; Pande, S.; Rao, J.N.; Podile, A.R. (2001). Biological control of crown rot groundnut by Trichoderma harzianum and T. viride. Intl. Arachis Newsletter, 21, 39-40.

28. Klich, M.A. (2002). Identification of common Aspergillus species. Utrecht, The Netherlands, Centraalbureau voor Schimmelcultures. ISBN 90-70351-46-3

29. Kucuk, C.; Kivank, M. (2003). Isolation of Trichoderma Spp. and Determination of Their Antifungal, Biochemical and Physiological Features. Turk J Biol 27, 247-253.

30. Lee, Y.P.; Takahashi, T. (1966). An improved colorimetric determination of amino acids with the use of ninhydrin. Annalytical Biochemistry, 14, 71-73.

31. Limon, M.C.; Pintor-Toro, J.A.; Benítez, T. (1999). Increased antifungal activity of Trichoderma harzianum transformants that overexpress a 33 kDa chitinase, Phytopathol., 89, 254-261.

32. Lowry, O.W.; Rosebrough, N.J.; Farr, A.C.; Randall, R.J. (1951). "Protein measurements with folin-phenol reagent". J. Biol. Chem., 193, 255-257.

33. Lynch, J.M. (1990). Fungi as Atagonists. In: New Directions in Biological Control: Alternatives for Suppressing Agricultural Pests and Diseases, Liss, New York, pp. 243-253.

34. Malik, C.P.; Singh, S.P. (1980). Plant enzymology and histoenzymology. Kalyani Publishers, Ludhiana. pp 54-56, 71-72.

35. Marco, J.L.D.; Valadares-Inglis, M.C.; Felix, C.R. (2003). Production of hydrolytic enzymes by Trichoderma isolates with antagonistic activity against Crinipellis perniciosa the causal agent of witches broom of cocoa, Braz. J. Microbiol. 34, 33-38.

36. Prabhu, K.S.; Urs, S.D. (1998). Efficacy of bio agents for management of collar rots of groundnut caused by Aspergillus niger. Current Res. Uni. Agric. Sci. Bangalore. 27, 114-115.

37. Prameala, M.; Rajeswari, B.; Prasad, R.D.; Reddy, D.R.R. (2005). Bioefficacy of antagonist against Fusarium oxysporum $f$. sp. Carthami isolates inciting sunflower wilt. J. Mycol. Plant Pathol., 35, 2. 
38. Raju, M.R.B.; Murthy, K.V.M.K. (2000). Efficacy of Trichoderma spp. in the management of collar rot of groundnut caused by Aspergillus niger Van Tieghem. Indian J. Pl. Prot., 28, 197-199.

39. Rao, S.K.T.; Sitaramaih, K. (2000). Management of collar rot disease (A. niger) in groundnut with Trichoderma Spp. J. Mycol. Pl. Pathol., 30, 221-224.

40. Reissig, J.L.; Strominger, J.L.; Lefloir, L.F. (1955). A modified colorimetric method for the estimation of $\mathrm{N}$-acetyl amino sugars. J. Biol. Chem., 217, 959-966.

41. Sadasivam, S.; Manickam, K. (1992). Biochemical method for Agricultural sciences, Wiley Estern Limited, Coimbatore.

42. Samson, R.A.; Houbraken, J.A.M.P.; Kuijpers, A.F.A.; Frank, J.M.; Frisvad, J.C. (2004). New ochratoxin A or sclerotium producing species in Aspergillus section Nigri. Studies Mycol., 50, 45-46.

43. Samson, R.A.; Houbraken, J.; Summerbell, R.C.; Flannigan, B.; Miller,
J.D. (2001). Common and important species of fungi and actinomycetes in indoor environments. In: Microogranisms in Home and Indoor Work Environments. New York: Taylor \& Francis. pp. 287-292.

44. Shalini, S.; Kotasthane, A.S. (2007). Parasitism of Rhizoctonia Solani by strains of Trichoderma spp. EJEAF Chemistry. 6, 2272-2281.

45. Sinclair, J.B.; Dhingra, O.D. (1985). Basic Plant Pathology Method. CRC Press, Inc. Corporate Blud, M.W. Boca Rotam, Florida, pp. 295 315.

46. Sivan, A.; Chet, I. (1993). Integrated Control of Media on Growth and Interactions between a range of Soil borne Glasshouse Pathogens and Antagonistic Fungi. Phytopathol., 10, 127-142.

47. Watanabe, N. (1984). Antagonism by various kind of trichoderma fungi to soil born plant pathogen Bulletin of Faculty of Agriculture, Maiji University, Japan 66, 45-50. 